\title{
Incompatibility Alleles in Portuguese Hazelnut Landraces
}

\author{
Sandra Martins, ${ }^{1}$ Mercè Rovira, ${ }^{2}$ Ana Paula Silva, ${ }^{3}$ and Valdemar Carnide ${ }^{1,4}$ \\ ${ }^{1}$ Department of Genetics and Biotechnology, University of Trás-os-Montes and Alto Douro, 5001-801 Vila Real, Portugal \\ ${ }^{2}$ Institut de Recerca i Tecnologia Agroalimentàries, IRTA-Mas de Bover, 43120 Constantí, Spain \\ ${ }^{3}$ Centre for the Research and Technology of Agro-Environmenta and Biological Sciences, \\ University of Trás-os-Montes and Alto Douro, 5001-801 Vila Real, Portugal \\ ${ }^{4}$ Institute for Biotechnology and Bioengineering, Centre of Genomics and Biotechnology, \\ University of Trás-os-Montes and Alto Douro, 5001-801 Vila Real, Portugal
}

Correspondence should be addressed to Sandra Martins, sandram@utad.pt

Received 13 April 2012; Accepted 23 May 2012

Academic Editors: T. Koba, C. Magill, and L. Parisi

Copyright (C 2012 Sandra Martins et al. This is an open access article distributed under the Creative Commons Attribution License, which permits unrestricted use, distribution, and reproduction in any medium, provided the original work is properly cited.

In many higher plants, selffertilization and genetically related individuals are prevented by pollen-stigma incompatibility. In the genus Corylus, incompatibility is of the sporophytic type and controlled by a single locus with multiple alleles. The objective of this study is to identify the $S$-alleles present in a collection of Portuguese landraces in order to select the most appropriate landraces for establishment of future orchards and for breeding programmes. Ten major Portuguese hazelnut landraces were submitted to controlled pollinations in the field, with 18 genotypes whose $S$-alleles are known. The pollen tubes were observed at 100X under a florescence microscope to evaluate their development. Three landraces were revealed to have $S_{2}$ allele, two have $S_{5}$, and four have one of the $S_{3}, S_{5}, S_{10}$, and $S_{18}$ alleles. One landrace was compatible with the $18 S$-alleles tested and for two landraces, it was possible to identify both alleles. The information of the self-incompatibility relationship between these old cultivars is obviously useful for selecting the most suitable pollinators for planning new orchards and for new cultivars development.

\section{Introduction}

Self-incompatibility is a widespread phenomenon which promotes outcrossing in flowering plants. Compatibility relationships, originally determined for the purpose of making successful hybridizations, suggest that sporophytic incompatibility exists in the European hazelnut, Corylus avellana L. Reciprocal differences occur, indicating dominance, and the site of the reaction is the stigmatic surface. This type of genetic control was first reported for Crepis foetida L. [1] and Parthenium argentatum Gray [2] and has subsequently been reported in other members of the Asteraceae (Compositae), Brassicaceae (Cruciferae), and other families [3]. In the sporophytic incompatibility system, the pollen exine carries the product of one or two $S$-alleles, and the phenotype of the pollen is determined by the plant that produces the pollen [4]. Pollen rejection in the sporophytic system is controlled by the interaction of the $S$-alleles expressed by the pistil and the pollen, and not by the haploid genotype of the pollen. Molecular studies of sporophytic self-incompatibility (SSI) have been carried out exclusively in Brassica. The self-incompatibility response occurs in the stigmatic papillary cells that carry the plasma membraneanchored S receptor kinase (SRK) gene [5] on their surface and an S-locus glycoprotein (SLG) in the cell wall [6]. Both are highly polymorphic and SLG shares a high degree of sequence identity with the extracellular domain of SRK. Silva et al. [7] and Takasaki et al. [8] showed that SRK is the primary determinant of self-incompatibility in the pistil, and that SLG acts to promote the full manifestation of the SI response through an unknown mechanism.

Self-incompatibility in hazelnut is of the sporophytic type and under the control of a single locus with multiple alleles [3]. The stigmatic surface is the site of the incompatibility reaction [9]. To date, $31 \mathrm{~S}$-alleles have been identified [10-12] (Mehlenbacher, pers. comm.). All are codominant in the pistil, although they may show codominance or dominance in the pollen [10]. Research in several countries has 
TABLe 1: Origin of the Portuguese hazelnut landraces studied.

\begin{tabular}{lccc}
\hline Accessions & County & Longitude & Latitude \\
\hline $\mathrm{Ca} 1$ & Viseu & $7^{\circ} 56^{\prime} \mathrm{W}$ & $40^{\circ} 39^{\prime} \mathrm{N}$ \\
$\mathrm{Ca} 3$ & Viseu & $7^{\circ} 56^{\prime} \mathrm{W}$ & $40^{\circ} 39^{\prime} \mathrm{N}$ \\
$\mathrm{Ca} 4$ & Viseu & $7^{\circ} 48^{\prime} \mathrm{W}$ & $40^{\circ} 39^{\prime} \mathrm{N}$ \\
$\mathrm{Ca} 5$ & Viseu & $7^{\circ} 54^{\prime} \mathrm{W}$ & $40^{\circ} 39^{\prime} \mathrm{N}$ \\
$\mathrm{Ca} 7$ & Felgueiras & $8^{\circ} 10^{\prime} \mathrm{W}$ & $41^{\circ} 22^{\prime} \mathrm{N}$ \\
$\mathrm{Ca} 8$ & Felgueiras & $8^{\circ} 10^{\prime} \mathrm{W}$ & $41^{\circ} 22^{\prime} \mathrm{N}$ \\
$\mathrm{Ca} 9$ & Castelo de Paiva & $8^{\circ} 16^{\prime} \mathrm{W}$ & $41^{\circ} 02^{\prime} \mathrm{N}$ \\
$\mathrm{Ca} 10$ & Castelo de Paiva & $8^{\circ} 16^{\prime} \mathrm{W}$ & $41^{\circ} 02^{\prime} \mathrm{N}$ \\
$\mathrm{Ca} 11$ & Moimenta da Beira & $7^{\circ} 34^{\prime} \mathrm{W}$ & $40^{\circ} 57^{\prime} \mathrm{N}$ \\
$\mathrm{Ca} 12$ & Moimenta da Beira & $7^{\circ} 34^{\prime} \mathrm{W}$ & $40^{\circ} 57^{\prime} \mathrm{N}$ \\
\hline
\end{tabular}

TABle 2: Pollen testers (18) used to identify S-alleles in Portuguese hazelnut landraces. Alleles expressed in the pollen are underlined.

\begin{tabular}{|c|c|c|c|}
\hline Cultivar & $S$-alleles & Reference & Location \\
\hline Culplà & $9 \underline{10}$ & {$[16]$} & UTAD \\
\hline Butler & $2 \underline{3}$ & {$[32]$} & UTAD \\
\hline Pauetet & $\underline{18} 22$ & {$[32]$} & UTAD \\
\hline Tonda di Giffoni & $\underline{2} 23$ & {$[32]$} & UTAD \\
\hline Ronde du Piemont & $2 \underline{7}$ & {$[32]$} & UTAD \\
\hline Morell & $\underline{1} 2$ & {$[14]$} & UTAD \\
\hline Segorbe & 923 & {$[32]$} & UTAD \\
\hline Gunslebert & $\underline{5} 23$ & {$[16]$} & UTAD \\
\hline Vermellet & $2 \underline{16}$ & {$[33]$} & SPAIN \\
\hline Tombul & $4 \underline{12}$ & {$[10]$} & SPAIN \\
\hline Henneman \#3 & $\underline{6} \quad 10$ & {$[10]$} & SPAIN \\
\hline Mortarella & $2 \underline{17}$ & {$[10]$} & SPAIN \\
\hline Gem & $2 \underline{14}$ & {$[10]$} & USA \\
\hline OSU 447.015 & $\underline{26} \underline{26}$ & {$[13]$} & USA \\
\hline Buttner's Zeller & $11 \underline{27}$ & Mehlenbacher, pers. comm. & USA \\
\hline OSU 930.081 & $4 \underline{29}$ & Mehlenbacher, pers. comm. & USA \\
\hline OSU 1136.056 & $\underline{10} \underline{30}$ & Mehlenbacher, pers. comm. & USA \\
\hline The Shah & $\underline{14} \underline{30}$ & Mehlenbacher, pers. comm. & USA \\
\hline
\end{tabular}

Note: $S$-alleles not tested are 4, 8, 11, 15, 19, 20, 21, 22, 23, 24, 25, and 31 .

been carried out to determine the alleles present in different cultivars [13-19]. Cultivars may be cross-incompatible, so commercial orchards are planted with cross-compatible cultivars and pollinators that have overlapping flowering times to ensure good fruit set. In hazelnut breeding programs, incompatibility prevents making many desirable crosses, and in other cases it dictates the direction of the cross [10]. Some Portuguese hazelnut landraces have been identified with particular interesting traits. The objective of this study is to identify the $S$-alleles in these Portuguese landraces in order to select the most appropriate combinations for establishment of future orchards.

\section{Materials and Methods}

The ten most important Portuguese hazelnut landraces were selected (Table 1). They include four from Viseu county (Ca1, Ca3, Ca4, and Ca5), two from Felgueiras county (Ca7 and Ca8), two from Castelo de Paiva county (Ca9 and Ca10), and two from Moimenta da Beira county (Ca11 and Ca12).

A total of 18 genotypes with known $S$-alleles in the field collections at three locations were used as testers: eight at the University of Trás-os-Montes and Alto Douro (UTAD), Portugal, four at IRTA, Spain, and six at Oregon State University in Corvallis, USA (Table 2). Two to five branches of each selected landrace tree were emasculated by clipping catkins and were covered with Tyvek bags $(1 \times 0.5 \mathrm{~m})$ in January. This was done to isolate female inflorescences and prevent exposure to air-borne pollen. A second Tyvek bag was used to cover and protect the inner bag from damage by wind. Only female flowers from covered branches were used for incompatibility testing. When catkins of tester cultivars had elongated and were about to shed (stage Fm1, [20]), they were brought to the laboratory in the afternoon, laid on paper in a single layer, and held at room temperature (18$20^{\circ} \mathrm{C}$ ) overnight to allow the anthers to dehisce. 
TABle 3: Results of pollinating ten Portuguese hazelnut landraces with testers.

(a)

\begin{tabular}{|c|c|c|c|c|c|c|c|c|c|}
\hline$S$-alleles/accession & $\begin{array}{c}\text { Culplà } \\
\underline{10}\end{array}$ & $\begin{array}{c}\text { Butler } \\
\underline{3}\end{array}$ & $\begin{array}{c}\text { Pauetet } \\
\underline{18}\end{array}$ & $\begin{array}{c}\text { Tonda di Giffoni } \\
\underline{2}\end{array}$ & $\begin{array}{c}\text { Ronde du Piemont } \\
\underline{7}\end{array}$ & $\begin{array}{c}\text { Morell } \\
\underline{1}\end{array}$ & $\begin{array}{c}\text { Segorbe } \\
\underline{9}\end{array}$ & $\begin{array}{c}\text { Gunslebert } \\
\underline{5}\end{array}$ & $\begin{array}{c}\text { Vermellet } \\
\underline{16}\end{array}$ \\
\hline $\mathrm{Ca} 1$ & $+^{\mathrm{a}}$ & - & + & + & + & + & + & + & + \\
\hline $\mathrm{Ca} 3$ & + & + & + & - & + & + & + & + & + \\
\hline $\mathrm{Ca} 4$ & + & + & + & - & + & + & + & + & + \\
\hline $\mathrm{Ca} 5$ & + & + & + & - & + & + & + & + & + \\
\hline $\mathrm{Ca} 7$ & + & + & - & + & + & + & + & + & + \\
\hline $\mathrm{Ca} 8$ & + & + & + & + & + & + & - & - & + \\
\hline $\mathrm{Ca} 9$ & + & + & + & + & + & + & - & - & + \\
\hline $\mathrm{Ca} 10$ & + & + & + & + & + & + & + & + & + \\
\hline Ca11 & $-^{\mathrm{b}}$ & + & + & + & + & + & + & + & + \\
\hline $\mathrm{Ca} 12$ & + & + & + & + & + & + & + & - & + \\
\hline
\end{tabular}

(b)

\begin{tabular}{|c|c|c|c|c|c|c|c|c|c|}
\hline$S$-alleles/accession & $\begin{array}{c}\text { Tombul } \\
\underline{12}\end{array}$ & $\begin{array}{c}\text { Gem } \\
\underline{14}\end{array}$ & $\begin{array}{c}447.015 \\
\underline{26}\end{array}$ & $\begin{array}{c}\text { Buttner } \\
\underline{27}\end{array}$ & $\begin{array}{c}930.081 \\
\underline{29} \\
\end{array}$ & $\begin{array}{c}1136.056 \\
10 \underline{30}\end{array}$ & $\begin{array}{l}\text { The Shah } \\
\underline{14} \underline{30}\end{array}$ & $\begin{array}{c}\text { Henneman no. } 3 \\
\underline{6}\end{array}$ & $\begin{array}{c}\text { Mortarella } \\
\underline{17}\end{array}$ \\
\hline $\mathrm{Ca} 1$ & + & + & + & + & + & + & + & + & + \\
\hline $\mathrm{Ca} 3$ & + & + & + & + & + & + & + & + & + \\
\hline $\mathrm{Ca} 4$ & + & + & + & + & + & + & + & + & + \\
\hline $\mathrm{Ca} 5$ & + & + & l & 1 & l & l & l & + & + \\
\hline $\mathrm{Ca} 7$ & + & + & + & + & + & + & + & + & + \\
\hline $\mathrm{Ca} 8$ & + & + & + & + & + & + & + & + & + \\
\hline $\mathrm{Ca} 9$ & + & + & + & + & + & + & + & + & + \\
\hline $\mathrm{Ca} 10$ & + & + & + & + & + & + & + & + & + \\
\hline Ca11 & + & + & + & + & + & - & + & + & + \\
\hline Ca12 & + & + & + & + & + & + & + & + & + \\
\hline
\end{tabular}

a $(+)$ : compatible combination.

$\mathrm{b}(-)$ : incompatible combination.

I: not evaluated.

The pollen was harvested next day and preserved in the freezer at $-20^{\circ} \mathrm{C}$ in glass vials. When the stigmas on bagged branches reached 2-5 mm (stage Ff2, [20]), they were pollinated in the field with the tester pollen. Each landrace was pollinated with pollen from different tester cultivars. One week to 10 days after pollinization, the flowers were collected and fixed in FAA (formalin-acetic-alcohol). The styles were squashed on a microscope slide in a drop of aniline blue. The pollen tubes were observed at 100X under the florescence microscope as described by Martin [21] and adapted to hazelnut styles by Romisondo [17].

\section{Results}

The $S$-alleles present in the Portuguese landraces were determined based on pollen tube development. In compatible crosses, pollen germinated well and produced masses of long parallel tubes with strongly fluorescing callose plugs. In incompatible crosses, pollen germinated at a lower rate and produced very short tubes which often curved or ended in a pronounced bulb. For these studies, fresh female flowers were used, as the quality of the female inflorescence is important in obtaining easily distinguishable reactions. For the ten landraces and 18 testers, it was possible to determine the compatibility of the combinations and thus some of the alleles present in the landraces (Table 3 ).

Of the 10 landraces tested, the landrace Cal was incompatible only with the $S_{3}$ tester "Butler." The second allele remained unknown. For landraces $\mathrm{Ca} 3, \mathrm{Ca} 4$, and $\mathrm{Ca} 5$, the presence of allele $S_{2}$ was indicated by incompatibility with pollen of the $S_{2}$ tester "Tonda di Giffoni." All three landraces were compatible with pollen of the other 16 testers (Figure 1). These three landraces were compatible with pollen of the other 17 testers. For landrace Ca7, incompatibility with tester "Pauetet" indicated the presence of $S_{18}$. The second allele in Ca7 was not determined, since pollen of the other 17 testers was compatible. Ca8 and Ca9 were incompatible with $S_{5}$ tester "Gunslebert" and $S_{9}$ tester "Segorbe" and thus have the genotype $S_{5} S_{9}$. Pollen expressing the remaining 15 alleles was compatible. Landrace Ca10 was 
TABLE 4: Summary of compatibility of female inflorescences of ten Portuguese hazelnut landraces with 18 pollen testers.

\begin{tabular}{lcc}
\hline Landraces & & Alleles \\
& Pistil rejects (incompatible) & Pistil accepts (compatible) \\
\hline Ca1 & $S_{3}$ & $S_{1}, S_{2}, S_{5}, S_{6}, S_{7}, S_{9}, S_{10}, S_{12}, S_{14}, S_{16}, S_{17}, S_{18}, S_{26}, S_{27}, S_{29}, S_{30}$ \\
Ca3 & $S_{2}$ & $S_{1}, S_{3}, S_{5}, S_{6}, S_{7}, S_{9}, S_{10}, S_{12}, S_{14}, S_{16}, S_{17}, S_{18}, S_{26}, S_{27}, S_{29}, S_{30}$ \\
Ca4 & $S_{2}$ & $S_{1}, S_{3}, S_{5}, S_{6}, S_{7}, S_{9}, S_{10}, S_{12}, S_{14}, S_{16}, S_{17}, S_{18}, S_{26}, S_{27}, S_{29}, S_{30}$ \\
Ca5 & $S_{2}$ & $S_{1}, S_{3}, S_{5}, S_{6}, S_{7}, S_{9}, S_{10}, S_{12}, S_{14}, S_{16}, S_{17}, S_{18}, S_{26}, S_{27}, S_{29}, S_{30}$ \\
Ca7 & $S_{18}$ & $S_{1}, S_{2}, S_{3}, S_{5}, S_{6}, S_{7}, S_{10}, S_{12}, S_{14}, S_{16}, S_{17}, S_{18}, S_{26}, S_{27}, S_{29}, S_{30}$ \\
Ca8 & $S_{5} S_{9}$ & $S_{1}, S_{2}, S_{3}, S_{6}, S_{7}, S_{10}, S_{12}, S_{14}, S_{16}, S_{17}, S_{18}, S_{26}, S_{27}, S_{29}, S_{30}$ \\
Ca9 & $S_{5} S_{9}$ & $S_{1}, S_{2}, S_{3}, S_{6}, S_{7}, S_{10}, S_{12}, S_{14}, S_{16}, S_{17}, S_{18}, S_{26}, S_{27}, S_{29}, S_{30}$ \\
Ca10 & & $S_{1}, S_{2}, S_{3}, S_{5}, S_{6}, S_{7}, S_{9}, S_{12}, S_{14}, S_{16}, S_{17}, S_{18}, S_{26}, S_{27}, S_{29}, S_{30}$ \\
Ca11 & $S_{10}$ & $S_{1}, S_{2}, S_{3}, S_{5}, S_{6}, S_{7}, S_{9}, S_{12}, S_{14}, S_{16}, S_{17}, S_{18}, S_{26}, S_{27}, S_{29}, S_{30}$ \\
Ca12 & $S_{5}$ & $S_{1}, S_{2}, S_{3}, S_{6}, S_{7}, S_{9}, S_{10}, S_{12}, S_{14}, S_{16}, S_{17}, S_{18}, S_{26}, S_{27}, S_{29}, S_{30}$ \\
\hline
\end{tabular}

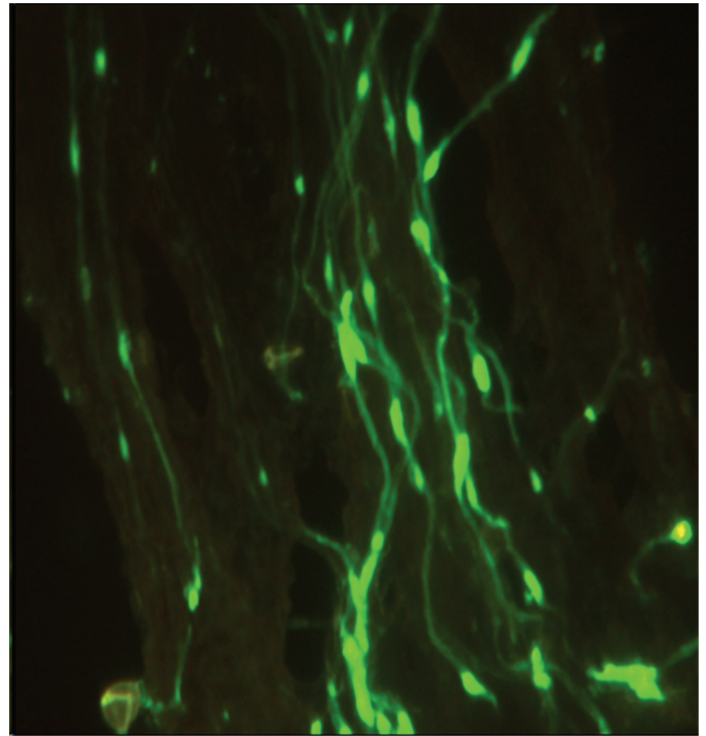

Figure 1: Compatible cross Ca5 x Butler $\left(S_{3}\right)$.

compatible with pollen of all 17 alleles tested. Landrace Ca11 had incompatibility with allele $S_{10}$, as its females were incompatible with pollen of the $S_{10}$ tester "Culplà." Ca11 was compatible with pollen expressed by the other 17 testers, so the identification of the genotype was incomplete $\left(S_{10} S\right.$ ?).

Landrace Ca12 was found to carry $S_{5}$, as its females were incompatible with "Gunslebert" pollen ( $S_{5}$ tester), but compatible with pollen expressing the other 16 alleles (Table 3). Pollen expressing each of the $12 S$-alleles $\left(S_{1}, S_{6}, S_{7}, S_{10}, S_{12}\right.$, $S_{14}, S_{16}, S_{17}, S_{26}, S_{27}, S_{29}$, and $S_{30}$ ) was compatible on females of all 10 landraces, indicating their absence in the landraces. The $S$-alleles of the tested landraces are summarized in Table 4. Pollen testers for the 12 alleles were not included in this study: $4,8,11,15,19,20,21,22,23,24,25$, and 31 .

\section{Discussion}

Self-incompatibility is classified as gametophytic and sporophytic ones based on whether the pollen behavior is determined by its own haploid genotype or by the diploid genotype of the plant that produces pollen $[22,23]$. It is a well-known phenomenon in Brassica. Corylus avellana L. is the only fruit species known to have sporophytic selfincompatibility. Molecular studies have greatly improved our understanding of sporophytic self-incompatibility in Brassica, where research has been focused on identifying and characterizing the pollen and pistil components of the incompatible response as well as other proteins and events that lead to pollen rejection [24]. Another major quest in self-incompatibility research is the identification of S-locus products in the pollen. For reasons that are not entirely clear, the experimental approaches that led to the cloning of the stylar products of the S-locus, the SLGs from Brassica spp., SRNases from solanaceous plants, and the small glycoproteins from Papaver rhoeas, have not proved to be useful in identifying the pollen products. Possibly, map-based approaches, similar to those used to clone the Pto gene from tomato [25], will be required. However, although identifying the product of the S-locus in pollen will provide another valuable piece of the puzzle, it will not reveal the whole story [23]. Several studies identified molecular markers linked to $S$-alleles but molecular studies of sporophytic self-incompatibility have been carried out exclusively in Brassica. Hampson et al. [26] attempted to use S-gene sequences from Brassica to find some homology with the S-genes of hazelnut, but they found that the Brassica S-genes were not useful for exploring the mechanism of sporophytic self-incompatibility in Corylus. They think that the sporophytic self-incompatibility genes of Brassica and Corylus have either diverged greatly during evolution or are of independent origin. Studies with RAPD and SCAR markers revealed that only the marker OPI07 $7_{750}$, closely linked to the $S_{2}$ allele, was useful for marker-assisted selection of individuals with the $S_{2}$ allele [27]. In apple and almond, with gametophytic incompatibility, $S$-allele genotyping can be performed using a protein-based method that looks at differences in S-RNase migration through a protein gel [28] or by PCR amplification of genomic DNA with "allele-specific" primers $[29,30]$. Van Nerum et al. [31] reexamined the self-incompatibility genotypes of apple cultivars containing putative "new" $S$-alleles using $S$-allelespecific PCR and sequence analysis. 
The details of sporophytic self-incompatibility in hazelnut are still completely unknown at the molecular level. In our study, we identified six $S$-alleles using controlled pollinations of bagged flowers in the field followed by fluorescence microscopy. In incompatible pollinations, pollen germination was delayed, and pollen tubes were distorted and failed to penetrate the stigma. Mehlenbacher [11] showed that the dominance relationship of alleles in the pollen is linear with seven levels, and this was used to choose the pollen testers for the present study. Recently identified $S$-alleles $S_{27}$, $S_{29}$, and $S_{30}$ have not yet been assigned to a level in the dominance hierarchy. Fluorescence microscopy is the most appropriate technique because to date no other techniques are available for $S$-allele identification. Three landraces, all from Viseu county, revealed the presence of the $S_{2}$ allele. For seven landraces (four from Viseu county, one from Felgueiras county, and two from Moimenta da Beira county), we were able to identify one allele. Females of all landraces showed compatibility with pollen expressing $S_{1}, S_{6}, S_{7}, S_{10}, S_{12}, S_{14}$, $S_{16}, S_{17}, S_{26}, S_{27}, S_{29}$, and $S_{30}$, thus, these alleles are absent in the landraces. For only two landraces (Ca8 and Ca9), it was possible to identify both alleles $\left(S_{5} S_{9}\right)$. Landrace Ca10 was compatible with all 18 testers. Tests with additional pollen testers will be needed to identify its $S$-alleles. In the other seven landraces, only one $S$-allele was identified. They may be homozygous at the S-locus. More likely, they carry a second allele not tested in this study. Homozygous testers are useful in basic pollination and incompatibility studies and would simplify allele identification. These ten Portuguese hazelnut landraces might be useful as parents in breeding new cultivars. Their use will require information on their $S$-genotypes. Interest in old cultivars for new orchards in Portugal is increasing due to their appreciable organoleptic and nutritional characteristics. Hazelnuts can be planted in response to commercial demand for high quality food and "functional" products. The information on the incompatibility relationships among these landraces is obviously useful for selecting the most suitable pollinizers for new orchards.

\section{Acknowledgments}

This work was supported by the Ph.D. Grant SFRH/BD/ $40686 / 2007$ attributed by the Portuguese Foundation of Science and Technology (FCT). The authors express their gratitude to S. A. Mehlenbacher of Oregon State University for sending pollen of several testers and for his critical review of this paper and valuable suggestions.

\section{References}

[1] M. B. Hughes and E. B. Babcock, "Self-incompatibility in Crepis foetida (L.) subsp., rhoeadifolia (Bieb.) Schinz et Keller," Genetics, vol. 35, pp. 570-588, 1950.

[2] D. U. Gerstel, "Self-incompatibility studies in guayule II. Inheritance," Genetics, vol. 35, pp. 482-505, 1950.

[3] M. M. Thompson, "Genetics of incompatibility in Corylus avellana L," Theoretical and Applied Genetics, vol. 54, no. 3, pp. 113-116, 1979.
[4] G. Me, L. Radicati, R. Vallania, M. L. Miaja, N. Valentini, and G. Pancheri, "Research on the genetics of incompatibility in Corylus," Acta Horticulturae, vol. 538, pp. 477-841, 2000.

[5] J. C. Stein, B. Howlett, D. C. Boyes, M. E. Nasrallah, and J. B. Nasrallah, "Molecular cloning of a putative receptor protein kinase gene encoded at the self-incompatibility locus of Brassica oleracea," Proceedings of the National Academy of Sciences of the United States of America, vol. 88, no. 19, pp. 8816-8820, 1991.

[6] J. B. Nasrallah, T. H. Kao, M. L. Goldberg, and M. E. Nasrallah, "A cDNA clone encoding an S-locus-specific glycoprotein from Brassica oleracea," Nature, vol. 318, no. 6043, pp. 263267, 1985.

[7] N. F. Silva, S. L. Stone, L. N. Christie et al., "Expression of the $S$ receptor kinase in self-compatible Brassica napus cv. Westar leads to the allele-specific rejection of self-incompatible Brassica napus pollen," Molecular and General Genetics, vol. 265, no. 3, pp. 552-559, 2001.

[8] T. Takasaki, K. Hatakeyama, G. Suzuki, M. Watanabe, A. Isogai, and K. Hinata, "The S receptor kinase determines selfincompatibility in Brassica stigma," Nature, vol. 403, no. 6772, pp. 913-916, 2000.

[9] C. R. Hampson, A. N. Azarenko, and A. Soeldner, "Pollenstigma interactions following compatible and incompatible pollinations in hazelnut," Journal of the American Society for Horticultural Science, vol. 118, no. 6, pp. 817-819, 1993.

[10] S. A. Mehlenbacher and M. M. Thompson, "Dominance relationships among S-alleles in Corylus avellana L," Theoretical and Applied Genetics, vol. 76, no. 5, pp. 669-672, 1988.

[11] S. A. Mehlenbacher, "Revised dominance hierarchy for Salleles in Corylus avellana L," Theoretical and Applied Genetics, vol. 94, no. 3-4, pp. 360-366, 1997.

[12] M. M. Thompson, "Incompatibility alleles in Corylus avellana L. cultivars," Theoretical and Applied Genetics, vol. 55, no. 1, pp. 29-33, 1979.

[13] V. Erdogan, A. I. Koksal, S. A. Mehlenbacher, and H. Kurt, "Preliminary results of incompatibility alleles expressed in pollen of Turkish hazelnut cultivars," Acta Horticulturae, vol. 686, pp. 157-162, 2005.

[14] E. Germain, P. Leglise, and F. Delort, Analyse du Système D'incompatibilité Pollinique Observé Chez le Noisetier Corylus avellana L., 1er. Colloque sur Recherches Fruitières, Bordeaux, France, 1981.

[15] E. Germain, Physiology of Reproduction in Filbert (Corylus avellana L.): Flowering and Fruiting, Convegno Internazionale sul Nocciuolo, Avelino, Italy, 1983.

[16] S. A. Mehlenbacher, "Testing compatibility of hazelnut crosses using fluorescence microscopy," Acta Horticulturae, vol. 44, pp. 167-171, 1997.

[17] P. Romisondo, "Alcuni aspetti della biologia fiorale del nocciuolo "Tonda Gentile delle Langue". II Contributo," Fruticoltura, vol. 11-12, pp. 887-895, 1965.

[18] M. Rovira, "Fórmulas alelicas de incompatibilidad polínica en el avellano (Corylus avellana L.)," Investigación Agraria. Producción y Protección Vegetal, vol. 4, no. 1, pp. 59-70, 1989.

[19] P. Zannini, G. Me, L. Radicati, S. Sacerdote, and R. Vallania, acquisizioni Sulla Compatibilita Gamica fra le Cultivar di Nocciuolo e loro Riflessi in Rapport alla Scelta degli Impollinatori. 1093, Convegno Internazionale sul Nocciuolo, Avelino, Italia, 1983.

[20] F. Bergougnoux, E. Germain, and J. P. Sarraquigne, "Le noisetier, production et culture," INVUFLEC, Paris, France, 1978. 
[21] F. W. Martin, "Staining and observing pollen tubes in the style by means of fluorescence," Stain Technology, vol. 34, no. 3, pp. 125-128, 1959.

[22] F. C. H. Franklin, M. J. Lawrence, and V. E. Franklin-Tong, "Cell and molecular biology of self-incompatibility in flowering plants," International Review of Cytology, vol. 158, pp. 164, 1995.

[23] D. P. Matton, N. Nass, A. E. Clarke, and E. Newbigin, "Selfincompatibility: how plants avoid illegitimate offspring," Proceedings of the National Academy of Sciences of the United States of America, vol. 91, no. 6, pp. 1992-1997, 1994.

[24] J. Halász, A. Hegedus, and A. Pedryc, "Review of the molecular background of self-incompatibility in rosaceous fruit trees," International Journal of Horticultural Science, vol. 12, no. 2, pp. 7-18, 2006.

[25] G. B. Martin, S. H. Brommonschenkel, J. Chunwongse et al., "Map-based cloning of a protein kinase gene conferring disease resistance in tomato," Science, vol. 262, no. 5138, pp. 1432-1436, 1993.

[26] C. R. Hampson, G. D. Coleman, and A. N. Azarenko, "Does the genome of Corylus avellana L. contain sequences homologous to the self-incompatibility gene of Brassica?" Theoretical and Applied Genetics, vol. 93, no. 5-6, pp. 759-764, 1996.

[27] K. W. Pomper, A. N. Azarenko, N. Bassil, J. W. Davis, and S. A. Mehlenbacher, "Identification of random amplified polymorphic DNA (RAPD) markers for self-incompatibility alleles in Corylus avellana L," Theoretical and Applied Genetics, vol. 97, no. 3, pp. 479-487, 1998.

[28] R. Bošković and K. R. Tobutt, "Correlation of stylar ribonuclease isoenzymes with incompatibility alleles in apple," Euphytica, vol. 107, no. 1, pp. 29-43, 1999.

[29] G. A. Janssens, I. J. Goderis, W. F. Broekaert, and W. Broothaerts, "A molecular method for $S$-allele identification in apple based on allele-specific PCR," Theoretical and Applied Genetics, vol. 91, no. 4, pp. 691-698, 1995.

[30] M. Tamura, K. Ushijima, H. Sassa et al., "Identification of selfincompatibility genotypes of almond by allele-specific PCR analysis," Theoretical and Applied Genetics, vol. 101, no. 3, pp. 344-349, 2000.

[31] I. Van Nerum, M. Geerts, A. Van Haute, J. Keulemans, and W. Broothaerts, "Re-examination of the self-incompatibility genotype of apple cultivars containing putative "new" $S$ alleles," Theoretical and Applied Genetics, vol. 103, no. 4, pp. 584-591, 2001.

[32] E. Germain and J. P. Sarraquigne, Le Noisetier, Centre Technique Interprofesionnel des Fruits et Légumes (CTIFL), Paris, France, 2004.

[33] M. M. Thompson, "Unpublished transcript from tape recorded at Harrison's Trees- Maxine Thompson describes hazelnuts imported by NZTCA," 1981. 


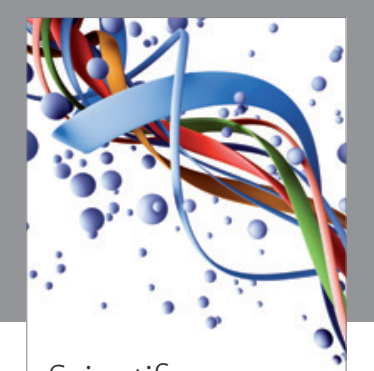

Scientifica
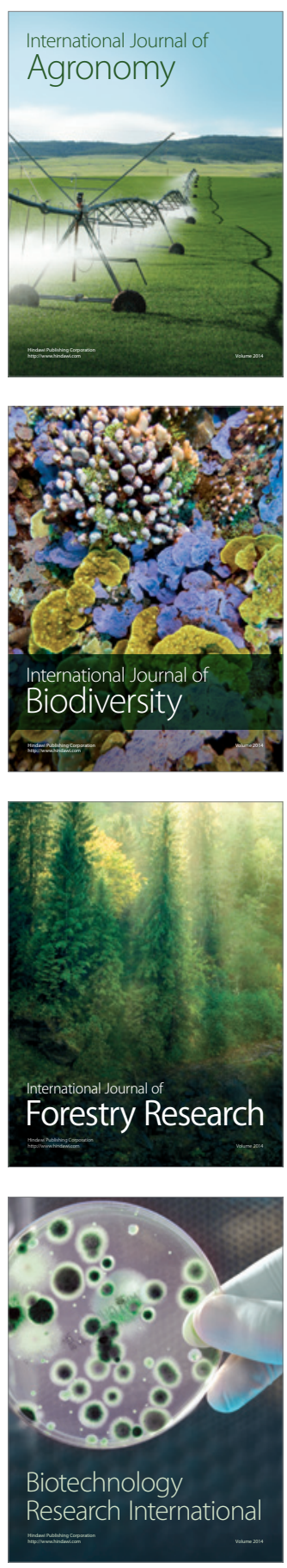
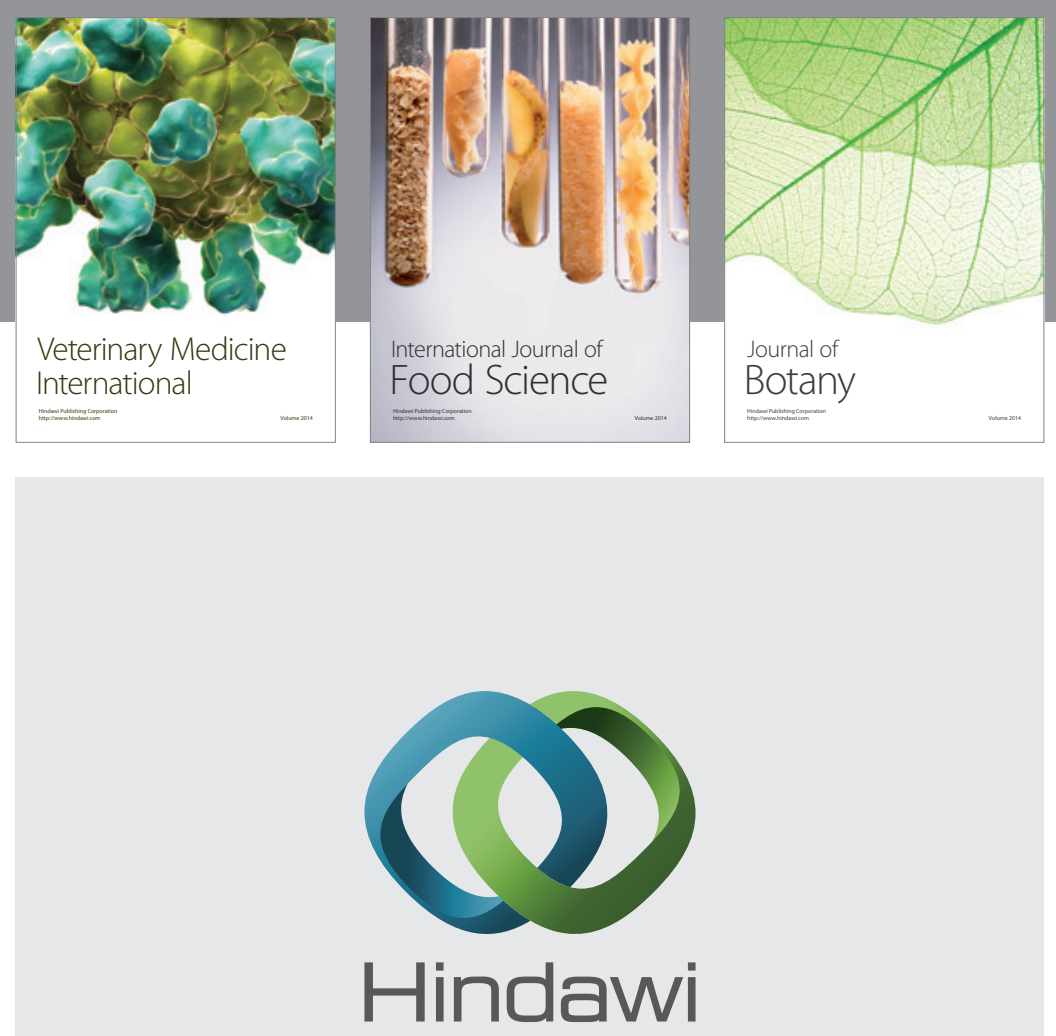

Submit your manuscripts at

http://www.hindawi.com
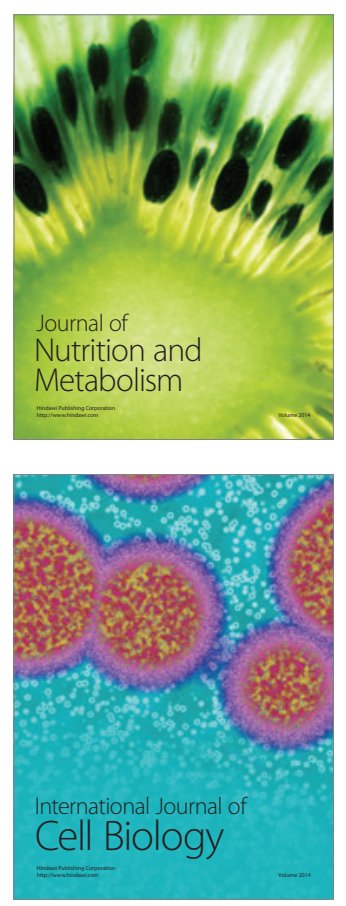
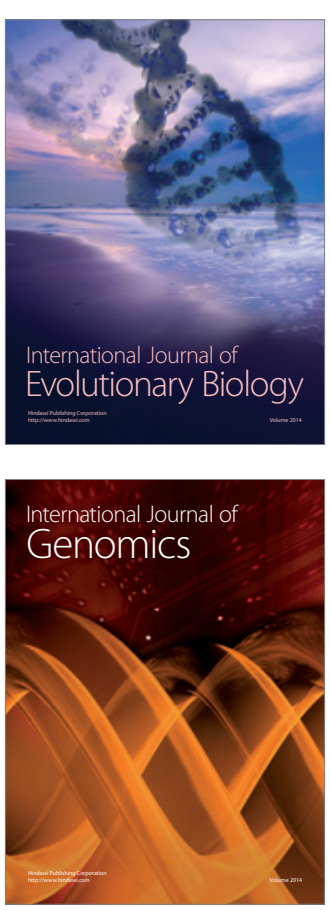
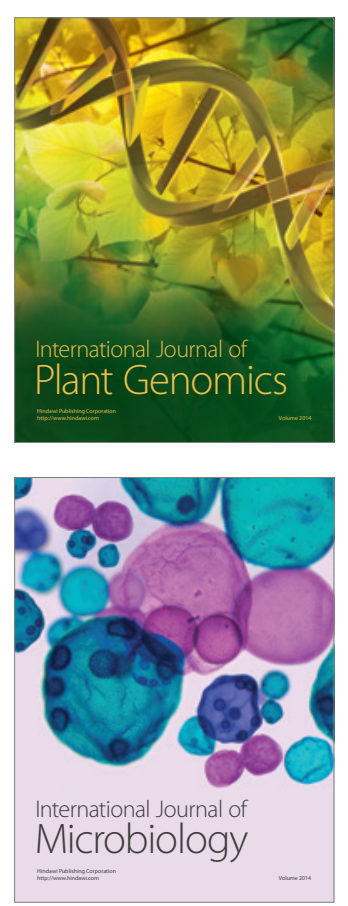

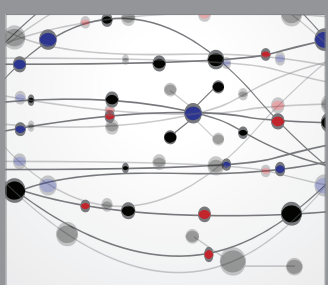

The Scientific World Journal
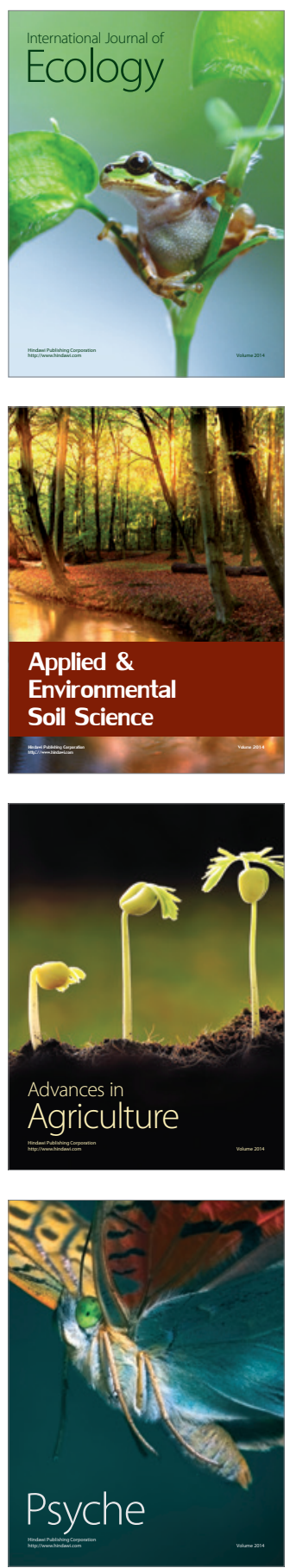